\title{
RISK MANAGEMENT IN PUBLIC FINANCE SYSTEM OF UKRAINE UNDER GLOBAL CHALLENGES
}

\author{
Diana TRETIAK (1) 1 , Nataliia MIEDVIEDKOVA®2* \\ ${ }^{1}$ Department of Insurance, Banking and Risk Management, Faculty of Economics, \\ Taras Shevchenko National University of Kyiv, 60 Volodymyrska Str., 01033 Kyiv, Ukraine \\ ${ }^{2}$ Department of Finance, Faculty of Economics, Taras Shevchenko National University of Kyiv, \\ 60 Volodymyrska Str., 01033 Kyiv, Ukraine
}

Received 28 February 2021; accepted 01 April 2021

\begin{abstract}
Purpose - to analyze the current state of risk management in Public Finance System of Ukraine and prefer recommendations for its improvement.

Research methodology - the structural-functional method (for revealing the influence mechanism of public finance risks on main indicators of Public Finance System), the comparison method (for comparing the main indicators of Public Finance System between Ukraine and other countries).

Findings - recommendations for reducing of public finance risks will provide the budget with reliable sources of incomes, optimize the structure of government spending, and improve the budget process in order to create conditions for enhancing the quality and efficiency of budget decisions.

Research limitations - some risks are only of a qualitative nature and cannot be measured to analyze the impact of risks on the main indicators of Public Finance System.

Practical implications - improvement of a risk-oriented method in Public Finance System under global challenges is an effective method of developing the existing Public Finance Management in Ukraine.

Originality/Value - risk management in Public Finance system under global challenges is a new stage of comprehensive relations which opens the way for further progressive reforms. A great importance is to use the experience of risk management measures gained by EU states, but also taking into account the peculiarities of socio-economic situation in Ukraine.
\end{abstract}

Keywords: Public Finance System, risk management, fiscal risks, public debt, budget expenditures, budget transparency, fiscal rules.

JEL Classification: G32, H7.

Conference topic: Contemporary Financial Management.

\section{Introduction}

The state of public finance is one of the most important factors in macroeconomic stabilization. Formation of public finance in Ukraine is significantly influenced by risks associated with the macroeconomic situation, in particular with the accumulated public debt, government guarantees, the activities of economic entities in the public sector of the economy, etc. In conditions of economic difficulties, arising financial risks are associated with the coverage of additional losses by the state, in particular, from the hostilities in the east of the country and COVID-19 pandemic.

Searching and identifying public finance risks, as well as improving their management in order to take into account their impact on budget indicators and take measures to minimize them, is an important direction for ensuring macroeconomic stability, full and timely financing of state expenditures from assigned functions, as well as increasing the stability of public finance and economic state security. Since the beginning of 2020, the world economy has faced the impact of the effect of COVID-19 disease, which has become a global challenge and blow for most countries, including Ukraine. The introduction of quarantine and measures to ensure the safety of citizens negatively affected the economic situation in the country and the implementation of the state budget targets.

\footnotetext{
*E-mail: nsmedvedkova@gmail.com
} 
Ukrainian scientists (Lyuty \& Kravchenko, 2014; Lunina, 2012; Blishchuk, 2017; Grechanichenko, 2018; Kozoriz, 2020) deal with theoretical and practical issues of risk management in Public Finance System. Researchers in the field of Public Finance considered the factors creating risks of stability of public finances of Ukraine (Danylenko \& Zymovets, 2015), the mechanism for preventing threats to the economic security of Ukraine (Rozhko \& Trygub, 2013; Rozhko, 2013, 2016; Varnaliy et al., 2016), improvement of the effectiveness of control measures for preventing risks in Public Finance System (Miedviedkova, 2016; Drozd et al., 2018). The results of these researches indicate that the risk management policy in the field of public finance in Ukraine has turned out to be far from being as effective as expected. Paying tribute to the developments of domestic economic scientists, we note that some issues require additional research, especially in the face of new challenges caused by the COVID-19 pandemic.

\section{Research methods}

Given the relevance of the study, the purpose of this paper is to analyze risk management in the field of public finance, research foreign experience and develop recommendations for its improvement in Ukraine. The object of the research is public finance in the context of potential financial instability; the subject is the ability of the public finance sector of Ukraine to withstand risks and threats.

Risk management in Public Finance System is the basis of the fundamental research methodology. Methods of theoretical generalisation were applied to study and systematise risks in Public Finance System and public policy concepts to ensure economic security (Lunina, 2012; Lyuty \& Kravchenko, 2014; Danylenko \& Zymovets, 2015; Varnaliy et al., 2016). Scientific and methodical approach was used to budget strategizing (Rozhko et al., 2020). Systematic approach was used in order to determine the types and elements of public financial control for preventing risks in Public Finance System (Miedviedkova, 2016; Drozd et al., 2018). Some authors used conceptual approaches to the essence of risks in Public Finance System (Lunina, 2012; Lyuty \& Kravchenko, 2014; Danylenko \& Zymovets, 2015; Hasanov, 2017). The system structural analysis was applied in the study of priorities in ensuring the economic security of the national economy (Varnaliy et al., 2016). Groupings and tabular method were used to characterize types of risks in public finance system (Lunina, 2012; Hasanov, 2017; Varnaliy et al., 2016).

To achieve the goal of this paper, we used general scientific and special methods, such as:

- the structural-functional method (for disclosure the mechanism of risk management in Public Finance System). Thus, we used this method for revealing the influence mechanism of public finance risks on main indicators of Public Finance System. First, we identified the risks of Public Finance System, revealed their interconnection within one system, grouped them and defined the degree of their impact on public finance indicators (Figure 1). Having identified the weaknesses of Public Finance System, we defined the directions for developing recommendations to minimize these risks.

- the comparison method (for comparing the main indicators of Public Finance System between Ukraine and other countries). Firstly, this method was used during the review of macroeconomic risks: we used the indicator of dynamics of the decline in real GDP rates in Europe and Ukraine. This investigation helped us to conclude that in the second quarter of 2020, multi-year lows of economic activity were recorded in both developed and developing countries, including Ukraine. We revealed how the negative conditions affected Ukraine in comparison with other countries.

Secondly, we compared countries according to the Open Budget Index since the insufficient public access to budget information from the central government on the collection and expenditure of public resources provokes mistrust and threatens in Public Finance System. The calculation of this index involves the provision of the assessment of the availability, timeliness and completeness of 10 key budget documents using 109 equivalent indicators and an assessment of each country on a scale from 0 to 100. Taking into account the global average index and indices of

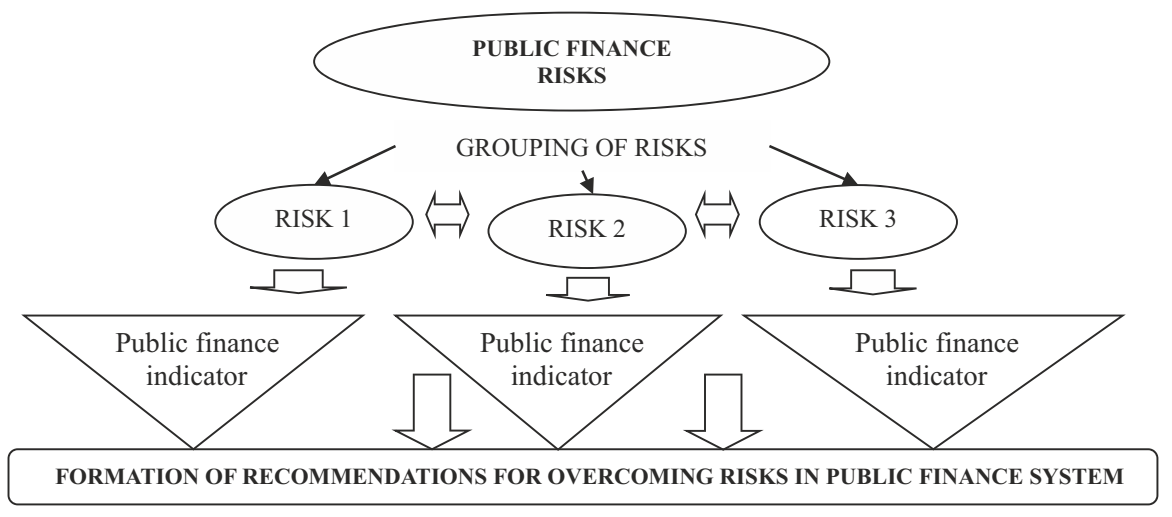

Figure 1. The structural-functional method in Public Finance System (source: compiled by the authors) 
neighboring countries helped us to see the country positioning and understand if we are on the right track to achieve the goal.

Thirdly, we found that in order to prevent the negative impact of factors on the country's financial system, the governments of many countries use fiscal rules. We consiered fiscal rules in detail by country grouping for analyzing and developing recommendations for Ukraine.

Fourthly, in order to understand the progress achieved by Ukrainian government in meeting public finance indicators, we studied the period in recent years and assessed the dynamics which made it possible to understand the drawbacks and risks of Public Finance System. In turn, it gives impetus to the formation of recommendations.

\section{The essence of risks in Public Finance System and their characteristics}

Risks in the field of public finance mean the likelihood of deviation of the amounts of government revenues, expenditures and borrowings from their expected (planned) amounts during certain budget periods of one, three or more years.

According to the Order of the Cabinet of Ministers of Ukraine "On Approval of the Strategy for Increasing the Efficiency of Business Entities in the State Sector of the Economy" (dated May 27, 2015 No. 662-r), there are a number of fiscal risks to the functioning of state-owned enterprises, which are caused by: 1) changes in macroeconomic conditions affecting the activities of business entities; 2) low financial discipline of state-owned enterprises, which leads to the emergence of a potential need to reimburse their losses from the budget; 3 ) the presence of debt of state-owned enterprises, which is secured by state guarantees; 4) other obligations of such enterprises, including arrears in the payment of salaries.

In a paper published by the World Bank, a fiscal risk is defined as a source of financial stress that the government may face in the future (Grechanichenko, 2018). At the same time, fiscal risks, especially those associated with contingent liabilities, stem mainly from political decisions and fiscal opportunism to avoid complex adaptations and unpopular structural reforms.

Another interpretation of fiscal risks, which is contained in a study by specialists from the International Monetary Fund, concerns the potential difference between actual and expected fiscal results, for example, in terms of the budget balance or the amount of public debt (Everaert et al., 2009) or possible deviations of fiscal variables at the level that was expected at the time of the adoption of the budget or its forecast.

According to the research fellow Moldovan, risks for the stability of Public Finance System include an increase in the budget deficit, an increase in the debt burden on the budget, a shortage of liquidity in domestic markets, and a reduction in state budget revenues due to a decrease in fiscal pressure on the economy (Moldovan, 2011). Researcher Hasanov believes that fiscal risks can be classified into two large groups: 1) internal risks of the fiscal system; 2) risks that are external origin, including outside the country.

According to the research of scientists (Bilousova et al., 2013), in accordance with this conceptual model of risk identification, the level of security of the public finance sector is determined based on the following components.

1. Conditionally stationary component, which includes:

- indicators of the level of debt dependence of the state, its fiscal ability to fulfill obligations to repay the principal amount of debt determined by the ratio of public debt to government revenues and the share of external debt in the total amount of government debt;

- indicator of the level of economic development;

- government performance indicators;

- indicators of the quality of the institutional environment;

- an indicator of the level of government redistribution of GDP.

2. Dynamic component, determined on the basis of three groups of risks that can reduce the level of security in the public finance sector in the short term. These are, in particular:

- currency risks (the risk of depreciation of the national currency) generated in the event of a deterioration in the balance of payments indicators and grow with an increase in the total external debt of the country, including public external debt;

- risks of a shortfall in government revenues generated under the influence of objective factors and with an increase in the level of shadow economy, which leads to tax evasion. The indicators of the risks of shortfall in government revenues are the level of shadowing of the economy and the financial position of the real sector, which is assessed on the basis of indicators of the level of debt dependence of enterprises in the real sector, growth in sales amounts and profitability of equity capital. The risk of a shortfall in state revenues is manifested in the event of a deviation of the base from its projected level, deterioration in the solvency of enterprises due to the growth of debt dependence and a decrease in the level of profitability;

- risks of growth in public spending, which are generated in connection with the probable excess of the actual amount of public spending over the planned one in the event of changes to the budgets, which is identified by the indicator of unplanned public spending. 
There are many views on the definition of risk-based management, although they all have similar components. Androsova believes that "risk management is a system of risk management and economic relations arising in the process of this management" (Androsova \& Cherep, 2008). Bondarenko notes that "risk management is a system measures to identify, assess, prevent and insure risks and includes the strategy and tactics of management actions" (Bondarenko, 2003).

Public finance in Ukraine is sensitive to several significant fiscal risks, which include risks associated with stateowned enterprises and state property management; government debt and government guarantees; the financial sector; the configuration of the macroeconomic situation. These risks are also called fiscal risks and they are factors that can lead to deviation of revenues, expenditures, government budget deficit and public debt from the planned indicators (Figure 2). The reliability of fiscal policy is negatively affected by the lack of a comprehensive management system for these risks, has negative consequences for the sustainability of public debt and efficient allocation of public resources in accordance with the priorities of public policy.

1. Macroeconomic risks. In early 2020, Ukraine, like the vast majority of countries in the world, suffered from a significant negative shock to the economy, caused by restrictive and prohibitive measures to prevent the emergence and spread of COVID-19 caused by the coronavirus. The introduced quarantine measures had a shock effect on the economies of the countries and the enterprises of the service sector suffered the most, consumer demand decreased, business activity deteriorated, and the volume of global trade decreased. As a result, in the second quarter of 2020, multi-year lows of economic activity were recorded in both developed and developing countries, including Ukraine (Figure 3).

In the context of the financial crisis, the high dependence of tax revenues on the external economic environment has become apparent (Table 1).

2. Risks associated with government debt and government guarantees. The deviation of macroeconomic indicators (in particular GDP and the exchange rate of the national currency against foreign currencies) will also have an impact on the indicators of public debt and publicly guaranteed debt, since the level of public and publicly guaranteed debt, two-thirds of which is denominated in foreign currency, is sensitive to changes in the exchange rate and the external environment.

The introduction of a balanced fiscal policy and an increase in the efficiency of public debt management had a positive impact on the dynamics of debt. As of the end of 2019 , the ratio of public debt to GDP is about $44.3 \%$, and the ratio of public and publicly guaranteed debt to GDP is $50.3 \%$.

In June 2019, the government approved the Medium-Term Strategy for Public Debt Management for 2019-2022. It was expected that as a result of the action plan defined by the Strategy for the current and the next three years, the debt-to-GDP ratio will not exceed $43 \%$ by the end of 2022 . Along with this, the Strategy provides for the achievement of not only quantitative, but also qualitative goals aimed at reducing the risks of public debt (Figure 4).

3. Risks associated with the activities of public sector entities. A possible deterioration in the financial condition of enterprises, as well as an aggravation of risks in their activities, can lead to a significant decrease in tax and nontax payments to the budgets, including part of the net profit compared to the planned volume.

The main fiscal risks associated with the activities of business entities in the public sector of the economy, which may negatively affect the state budget indicators in 2021, may be:

1) a decrease in deductions of tax and non-tax payments, including a part of net profit, dividends on the state share (in comparison with the planned amount);

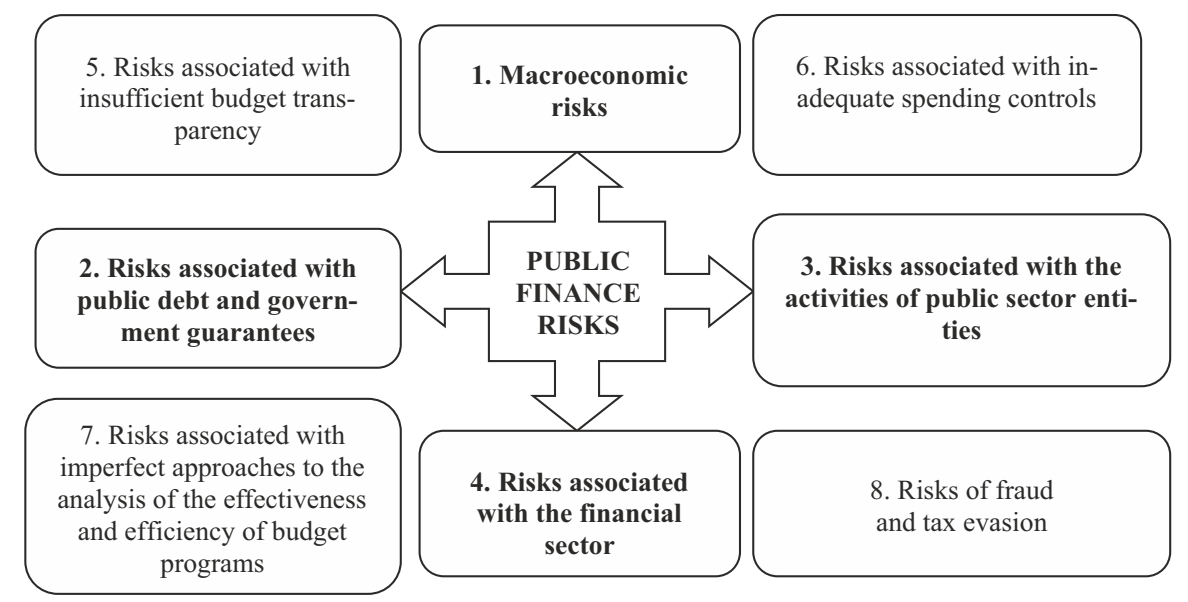

Figure 2. Types of public finance risks

(source: compiled by the authors) 


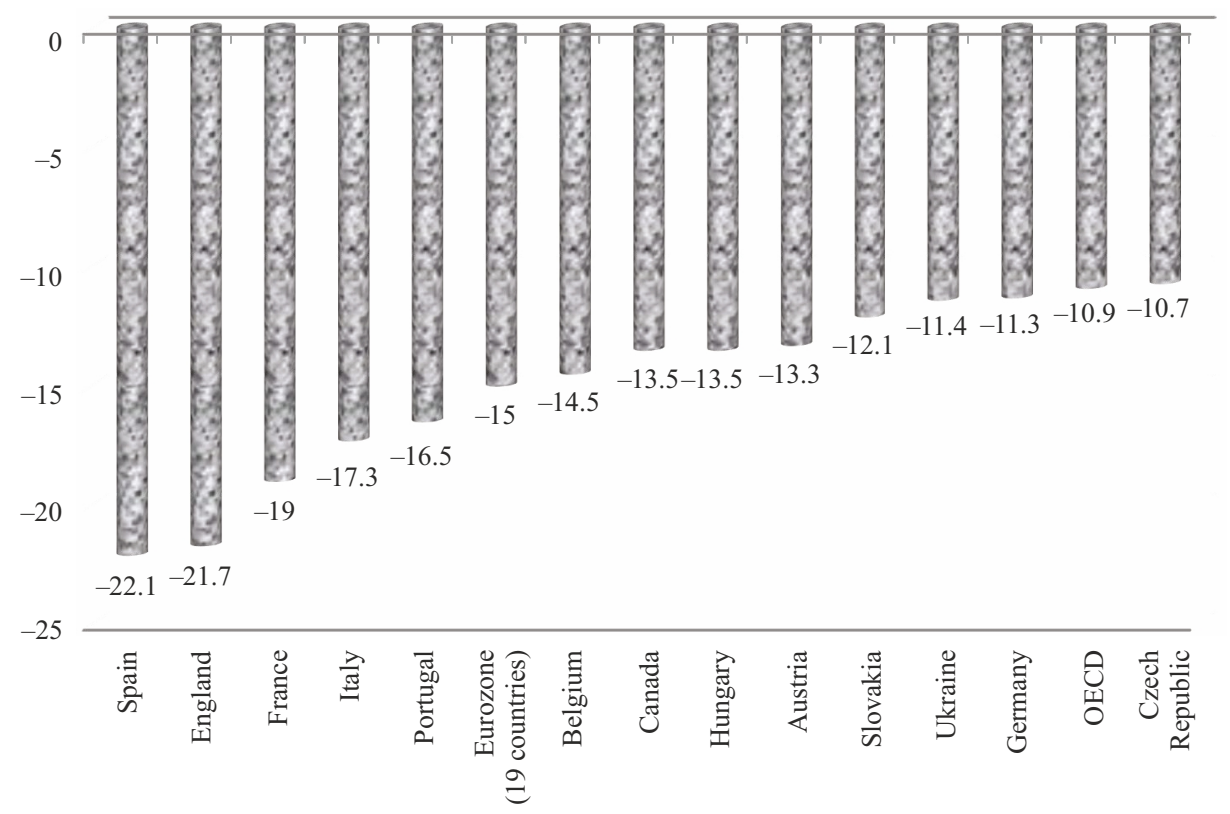

Figure 3. Dynamics of the decline in real GDP rates in the second quarter of 2020 in Europe and Ukraine (source: Ministry of Finance of Ukraine, 2021)

Table 1. Effect of changes in budget indicators in 2021 in case of realization of risks in the macroeconomic environment (UAH billion) (source: Ministry of Finance of Ukraine, 2021)

\begin{tabular}{|l|c|c|c|c|c|}
\hline Variables & $\begin{array}{c}\text { Formation of a } \\
\text { significant imbalance } \\
\text { in the labor market, } \\
\text { reduction in } \\
\text { employment }\end{array}$ & $\begin{array}{c}\text { Deficit of external } \\
\text { financing and } \\
\text { narrowing of access } \\
\text { to international capital } \\
\text { markets }\end{array}$ & $\begin{array}{c}\text { Decrease in the volume } \\
\text { of transit of natural } \\
\text { gas from the Russian } \\
\text { Federation through the } \\
\text { territory of Ukraine }\end{array}$ & $\begin{array}{c}\text { Obtaining } \\
\text { a low yield } \\
\text { of grain } \\
\text { crops }\end{array}$ & $\begin{array}{c}\text { Strengthening } \\
\text { hybrid threats to the } \\
\text { national economy } \\
\text { from the Russian } \\
\text { Federation }\end{array}$ \\
\hline Budget revenues & -10.6 & -6.7 & -5.8 & -8.7 & -1.9 \\
\hline $\begin{array}{l}\text { Personal income } \\
\text { tax }\end{array}$ & -2.3 & -1.4 & -1.2 & -1.9 & -0.4 \\
\hline Import VAT & -4 & -2.6 & -2.2 & -3.3 & -0.7 \\
\hline $\begin{array}{l}\text { Corporate income } \\
\text { tax }\end{array}$ & -1.9 & -1.2 & -1 & -1.6 & -0.3 \\
\hline Import duty & -0.5 & -0.3 & -0.3 & -0.4 & -0.1 \\
\hline Excise tax & -0.6 & -0.4 & -0.3 & -0.5 & -0.1 \\
\hline
\end{tabular}

2) provision of state support to business entities from the budget;

3) quasi-fiscal activities of business entities;

4) fulfillment by the state of guarantee obligations in case of impossibility of business entities to fulfill their obligations to creditors;

5) risks associated with the debt burden of business entities in foreign currency.

4. Risks associated with the financial sector. In the first half of 2020 , the fiscal risks associated with the functioning of the financial sector were not realized, namely, an increase in government spending on supporting state-owned banks and ensuring the stability of the financial system, supporting the system of guaranteeing deposits of individuals in connection with the recognition of bank insolvency.

First, according to the National Bank of Ukraine, in 2021 there is a high probability of growth in the volume of government spending to support state-owned banks. Secondly, the Fund for Guaranteeing Deposits of Individuals assessed the risks that exist today in the banking system of Ukraine and compared them with its financial capabilities per year. The amount of funds accumulated by the Fund indicates that by the end of this year the Fund will be able to make payments to depositors of insolvent banks without additional attraction of funds from the state budget. However, already in 2021, a shortage of funds in the amount of about UAH 8 billion is possible. The Fund does not have the ability to influence these risks in the banking system of Ukraine, as it evaluates its fiscal risks at this level. The likelihood of these risks being realized is moderate and their realization is possible only in conditions of a severe protracted deterioration of the economic situation in the country. 


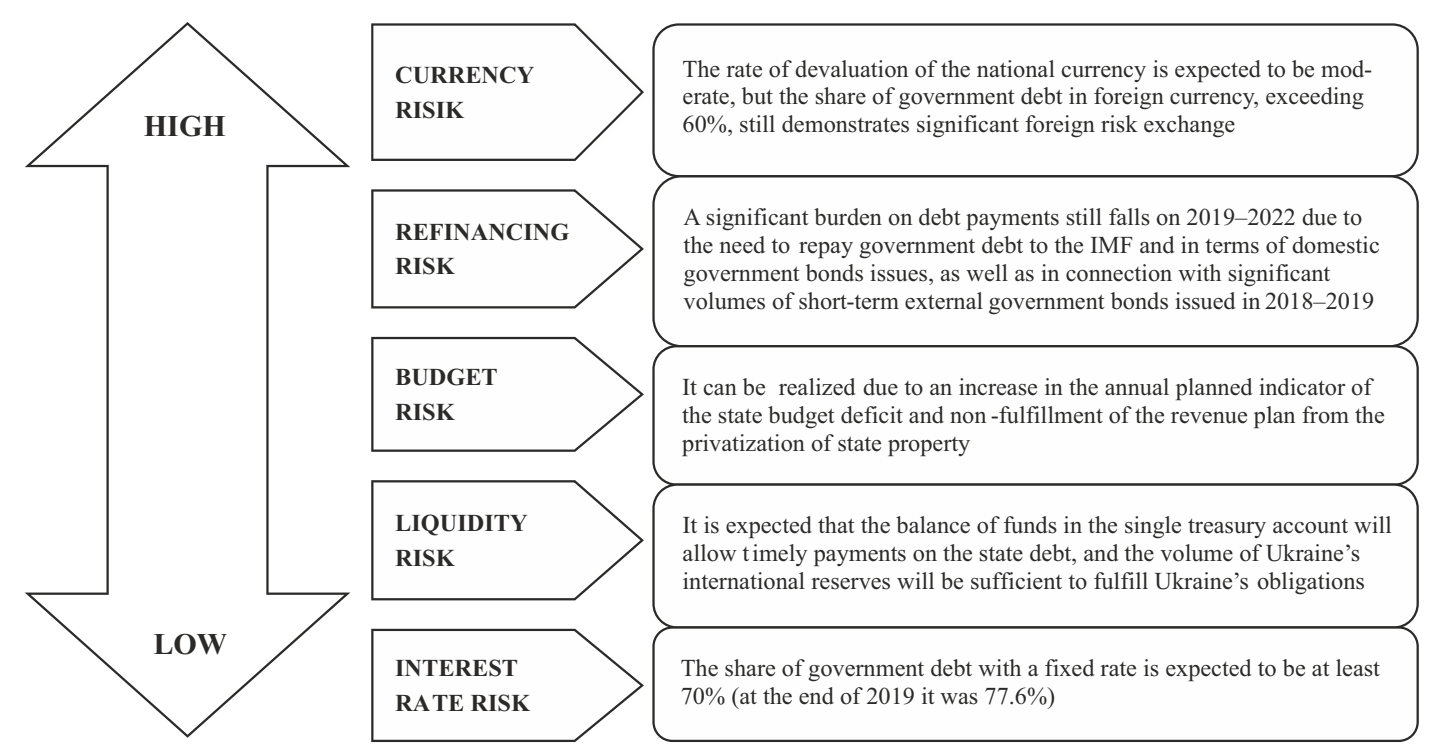

Figure 4. Fiscal risks in Public Debt Management in 2021

(source: compiled by the authors based on Ministry of Finance of Ukraine, 2021)

5. Risks associated with insufficient budget transparency. Insufficient transparency of information and public awareness of the budget indicates information hiding and increases risks in the field of public finance. One rating that uses criteria to assess public access to central government budget information is the Open Budget Survey. It assesses public access to information on how the central government collects and spends public resources. The availability, timeliness and completeness of eight key budget documents are assessed using 109 equivalent indicators and an assessment of each country on a scale from 0 to 100 .

In 2019, Ukraine's budget openness index reached 63 out of 100, which is higher than the global average score of 45 (Figure 5). An openness index of 61 or higher indicates that a country is likely to publish enough material to support meaningful public debate on the budget. This is a significant result in comparison with other countries (Poland -60 , Hungary -60 , Czech Republic -59 , Moldova -57 , Hungary -45 ).

6. Risks associated with inadequate spending controls that cause fraud and corruption in the public sector. Several steps have already been taken to prevent these risks. The most successful examples are the E-Data, ProZorro and DoZorro projects. E-Data is the official government information portal on the Internet that provides public information on the use of public funds and implements the idea of "Transparent Budget". The creation of the "Transparent Budget" system will reduce the level of fraud and corruption committed at all stages of the budget process, increase the efficiency of the use of budget funds and the international rating of Ukraine according to the Open Budget Index.

ProZorro is an electronic public procurement system that has replaced paper-based public tenders. This system uses commercial online platforms to register and connect users and organizers. The advantages of implementing this system are as follows: first, it allows everyone to control the budget process and budget execution; secondly, it promotes more efficient use of budgetary funds; thirdly, it reduces the likelihood of fraud and corruption at all stages of the budget process; finally, it improves the international rating of Ukraine on the open budget index.

DoZorro monitoring portal is a platform where each participant in the system (supplier, customer, supervisory authority, citizen) can provide feedback to a government customer or supplier, discuss and evaluate the conditions of a specific procurement, analyze the procurement of a separate government body or institution, prepare and submit official applications to regulatory authorities and much more.

For public activists and the media, the portal provides an opportunity to discuss a specific tender with potential and existing suppliers, find out their expert opinion on the correctness of the wording in the tender documents, get professional expertise, and the like. But the main thing is that it is a convenient tool for managing monitoring - after all, it has become extremely easy to keep records of the monitored procedures and violations found thanks to the portal.

Government customers can not only assess a specific supplier, but also analyze the feedback from the business and make appropriate changes in the procurement process and create their own risk management system. Completion of the integration process of the State Treasury Service of Ukraine, Prozorro and E-data will provide a full cycle of a specific contractual transaction from an offer through a contractual agreement with acts of acceptance and transfer of services of the bank accounts.

It is also worth noting that in recent years there has been active work on the implementation of a mechanism for interaction between the information and telecommunication system of the State Treasury of Ukraine with the electronic procurement system and the only web portal for the use of public funds, increasing openness and transparency in the activities of the State Treasury Service of Ukraine. 


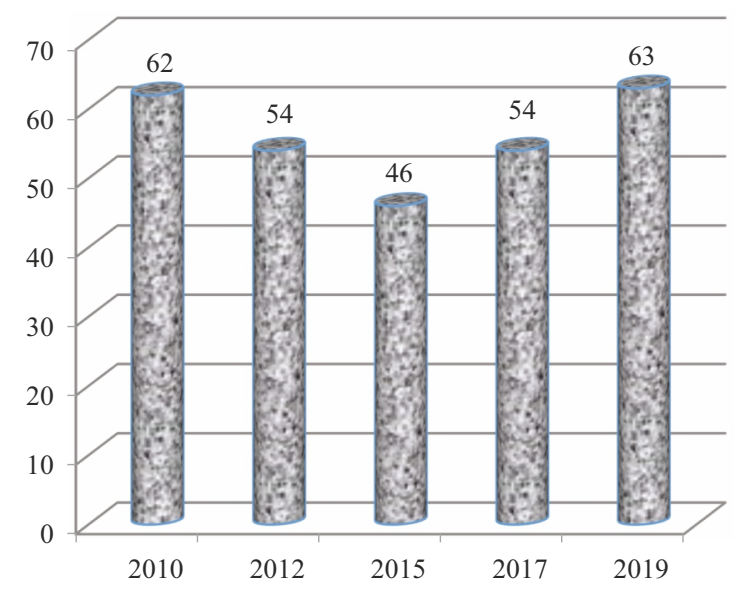

Figure 5. Index of openness of the budget during 2010-2019 (source: Open Budget Survey, 2019)

According to the powers granted by the Budget code of Ukraine, the Treasury bodies, in the event of violations of budget legislation by the administrators and recipients of budget funds, apply such measures of influence as:

- warnings about improper execution of budget legislation with a requirement to eliminate the violation;

- stopping operations with budgetary funds on accounts opened with the Treasury Service of Ukraine.

So, on the initiative of the Treasury bodies, operations with budget funds on the accounts of managers and recipients were stopped: in 2018 - more than 2100 cases, in 2019 - more than 2200. In 2019, the Treasury Service of Ukraine revealed more than 24 thousand facts of violations of budgetary legislation committed by managers and recipients of funds from state and local budgets for a total of UAH 19.7 billion.

7. Risks associated with imperfect approaches to the analysis of the effectiveness and efficiency of budget programs. A comprehensive assessment of the efficiency and effectiveness of expenditures is necessary in order to optimize the expenditures of the state budget in Ukraine. The purpose of this assessment is to identify inefficient spending and improve the effectiveness of sectoral policies. It will be possible to achieve this, since at the state level, the preparation of the Budget Declaration has been introduced as a document of state strategic planning, which defines the basic principles of budgetary policy for the medium term. The budget declaration contains, in particular, the aggregate ceiling of expenditures and the ceiling of expenditures of the main managers of the state budget funds, goals and indicators of the result of their activities (actual and expected for the medium term), an overall assessment of fiscal risks.

It is also important to note that the introduction of gender-oriented budgeting will be a progressive mechanism for increasing the efficiency and effectiveness of budget spending in Ukraine. Foreign experience shows that this will improve the quality of public services to meet the needs of various social groups, optimize the volume and structure of budget expenditures, and rationally use taxpayers' money. These measures will contribute to a consistent and predictable fiscal policy, strengthening fiscal discipline, assessing the impact of reforms and taking into account their consequences in the medium term, increasing the efficiency and effectiveness of public spending.

The new budget planning system is aimed at achieving strategic goals. The most important priority is to improve the quality of services provided from the state budget. The analysis of the sustainability of public finances in Ukraine should take into account the national characteristics of economic, financial and social development, as well as the risks that may cause adverse consequences.

8. Risks of fraud and tax evasion. At the beginning of January 2017, Ukraine committed itself to implementing the so-called Minimum Standard for the BEPS Action Plan. Ukraine's accession to BEPS means that Ukraine is obliged to apply minimum BEPS standards, including the following steps:

- effective counteraction to harmful tax practices using the principle of transparency;

- preventing the provision of benefits provided for by international treaties in improper circumstances;

- mandatory rules for disclosing information;

- to create more effective dispute resolution mechanisms.

In pursuance of the BEPS Action Plan, the Cabinet of Ministers of Ukraine, together with the NBU, submitted a draft law "On Amendments to the Tax Code of Ukraine in order to implement the Plan to counter the erosion of the tax base and the withdrawal of profits from taxation." In 2018, the Ministry of Finance and the NBU promulgated a draft of this law, which is designed to support financial stability in the country in the context of the transition to free movement of capital, improve the efficiency of tax regulation and introduce uniform requirements for the transparency of doing business in Ukraine according to international standards. 
The adoption of this bill will avoid recognition of Ukraine as a country which does not cooperate on taxation issues, and will also expand opportunities for Ukrainian business to carry out full-fledged activities in foreign markets, avoiding prejudice from foreign counterparties, banks and investors.

\section{Risk management process in Public Finance System}

At the present stage, the main risks for the country's economy and finances are the growing volatility of international markets, the fall in the country's international liquidity and public finance, government borrowing instruments and the growth of fiscal imbalances in the general government sector. The system of public finance was significantly influenced by such threats as a fall in the income base of business entities and the state budget, an increase in deficit, debt financing, quasi-fiscal transactions and non-payments (Lyuty \& Kravchenko, 2014).

It should be noted that the ineffectiveness of managerial actions in the Public Finance System affects the emergence of negative phenomena in all spheres of Ukrainian society. The low quality of management technologies implemented in the financial sector and the weakening of state management functions indicate that the Public Finance System requires fundamentally new approaches to the use of financial resources in the direction of their rational allocation, effective use and management.

It is the sphere of public finance that is the segment in the state that requires new management approaches and the search for new ways to improve the use of public funds. This problem is relevant and urgent in modern realities, therefore it requires increased attention and coordinated efforts. Effective public finance management should ensure the formation and distribution of public centralized and decentralized funds of funds necessary for the state and local authorities to perform their functions (Blishchuk, 2017).

As the modern foreign practice of management activity shows, it is important to actively use the risk management system in the field of public finance management in order to reduce the overall administrative burden on business entities and at the same time increase the level of efficiency of government bodies. Thus, Power in his study "The Risk Management of Everything: Rethinking the politics of uncertainty" noted that risk management is all the processes that take place around us and the organization of life can be shown based on the description of risks (Power, 2004).

Foreign experience in the field of public finance management assumes the transition from performance control to certain verification measures to control the achievement of the socio-economic effect from the activities of state institutions. The main targets are a decrease in the number of control measures and an increase in the efficiency of budget expenditures, because the effectiveness of the functioning of both the public and private sectors of the economy depends on the effective functioning of management activities and the speed of responding to the challenges of the time, as a result, filling budgets, regular financing of social payments (Grechanichenko, 2018).

Within national practice in of public finance management, the problems associated with making managerial decisions and ensuring the effectiveness of their implementation come to the fore. The influence of external factors requires adequate changes in the public finance management system. So, in recent years, a number of legislative acts have been adopted on issues of state internal financial control, such as the Strategy and Guidelines for organizing internal control by the administrators of budgetary funds in their institutions and in subordinate budgetary institutions, prepared on the basis of a manual on internal control standards for the public sector, developed by the Internal Control Committee of the International Organization of Supreme Audit Institutions (INTOSAI GOV 9100, n.d.), which is based on the COSO model. "Concept - COSO" is known as the concept of risk-oriented control, developed by the American Committee of Sponsoring Organizations of the Treadway Commission (COSO, n.d.) in 1992 and adopted as the basis for building internal control and risk management of an organization in many countries of the world (Grechanichenko, 2018).

Based on the principles of this Concept, the provisions of the International Standards of Internal Control in the Public Sector ISSAI 9100 (n.d.) International Standards Risk Management - Principles and Guidelines for ISO 31000 , it is possible to propose a mechanism for introducing risk-based management in the system of state internal financial control, which will be carried out in several stages:

1. regulatory methodological support;

2. organizational management decisions for the transition to risk-oriented management;

3. information, analytical and personnel support of the management process.

In our opinion, the risk is inherent in all aspects of the activities of public authorities. The main criterion for assessing the internal control system is the delta of risk reduction and achievement of goals. These activities are aimed at achieving results and should be carried out systematically. The systems approach, first of all, provides for the development of a broad organizational strategy for risk-based management, which can be directed as follows:

- development and approval of an internal document on the internal control system of the institution;

- a clear definition of the responsibilities and duties of structural units for the formation and operation of the institution's internal control system;

- implementation of risk assessment (identification and analysis of relevant risks on the way to achieving the goals of the governing body);

- prompt response to risks is carried out; 
- introduction of monitoring and control over measures to respond to risks;

- determination and use of an effective mechanism for making changes to the list of proposed measures to respond to risks (Grechanichenko, 2018).

Summing up, it should be noted that the state internal financial control is the important tool for public finance management, which allows achieving the necessary tasks and reducing the number of problematic issues related to the activities of central executive authorities and contributes to public administration in the event of changes in the environment, needs and priorities of society and the state.

Also, in the field of public finance management, it is important to develop and implement modern approaches to risk management associated with the implementation of government documents of all levels - from the very (programs, plans and strategies) - to the level of a specific technique.

\section{Recommendations for improving risk management in Public Finance System}

It is worth recognizing that the government of Ukraine has achieved certain positive results:

- state budget revenues increased significantly due to the growth of tax and non-tax revenues, including funds received from confiscation and as a result of the fight against corruption;

- budget expenditures are rationalized;

- the level of the minimum salary increased (Table 2).

Table 2. Indicators of Public Finance System for 2018-2020 (source: State Statistics Service of Ukraine, n.d.)

\begin{tabular}{|l|c|c|c|}
\hline \multicolumn{1}{|c|}{ Indicators } & 2018 & 2019 & 2020 \\
\hline State budget revenues, UAH million & 928108, & 998278,9 & 1076016,7 \\
\hline State budget expenditures, UAH million & 985842,0 & 1072891,5 & 1288016,7 \\
\hline State budget deficit, UAH million & $-59247,9$ & $-78049,5$ & $-217096,1$ \\
\hline Local budget revenues, UAH million & 562421,81 & 560527,91 & 471479,98 \\
\hline Minimum salary, UAH & 3723 & 4173 & 5000 \\
\hline Debt load, UAH million & 2168627,1 & 1998275,4 & 2551935,6 \\
\hline Debt / GDP, \% & $60,9 \%$ & $50,3 \%$ & $56,8 \%$ \\
\hline
\end{tabular}

Among the negative trends, the following should be noted:

- local budgets revenues decreased;

- there are certain negative changes to limit the budget deficit;

- despite the government's plans to gradually reduce the share of debt to GDP, the debt burden and accordingly the debt / GDP ratio increased in 2020 in comparison to the previous year.

Consequently, these trends indicate that it is necessary to focus on reducing and maintaining budget and debt indicators at a certain level. In 2021, the risks of the budgetary system remain high. First of all, this is due to negative macroeconomic and macro-fiscal trends that existed during the previous year, insufficient dynamics of the economy as whole, significant gaps between the growth rates of nominal and real GDP, revenues and expenditures of the general government sector, and chronic crises.

In modern conditions, the negative impact of fiscal risks has acquired particular relevance and become one of the central aspects of public finance management for most countries of the world. Leading international organizations operating in the financial and social sphere have developed a number of approaches to form effective instruments. So, to reduce the risks of public finances, consistent steps are needed to provide the budget with reliable sources of revenue, reform its expenditure side, as well as improve the budget process in order to create conditions for improving the quality and efficiency of budget decisions. Risk management of the state budget is carried out with the aim of increasing the level of security. The main recommendations are as follows:

1. Optimization of budget expenditures. To stabilize the state of the national economy in the long term in Ukraine, it is necessary to ensure an increase in the level and efficiency of the implementation of budgetary funds due to an increase in the share of expenditures aimed at developing and modernizing the economy, by reducing the cost of maintaining the bureaucratic apparatus, reducing tax pressure on business entities by improving the administration system taxes, which will help to increase the volume of enterprises' own funds, which can be used for investment purposes.

The main threat to the security of the public finance sector in Ukraine at the present stage is the deepening economic crisis, which is exacerbated by the deterioration of the financial condition of enterprises, banks, increases the risks of tax shortfalls by the state, leads to an increase in the state budget deficit and public debt.

Irrational sectoral structure of spending budgetary funds intended to support business entities. The sectoral section of the provision of state support indicates that its overwhelming majority is steadily directed to support the road sec- 
tor, agriculture and the coal industry. High-tech industries with the potential for import substitution remain without adequate funding. In particular, the processing industry receives a small amount of budgetary funds.

2. Application of fiscal rules. Most often, to minimize the negative impact of the risks of budget deficit is the use of fiscal rules. As international experience shows, that fiscal rules and regulations are introduced for various reasons, namely: ensuring macroeconomic stability (Japan); increasing confidence in the government's fiscal policy (Canada); ensuring the long-term sustainability of fiscal policy (New Zealand); minimizing negative externalities within a single monetary union or federation (EU countries).

IMF experts recommend developing fiscal rules based on targets adjusted for cyclical fluctuations. A prerequisite for the effective functioning of budget systems in modern conditions is the establishment of certain fiscal rules, even considered to be the most important innovations of the last two decades. Such norms usually limit key budget indicators (the level of budget deficit, government debt, total budget revenues and expenditures). And although empirical studies do not give an unambiguous answer to the question whether the introduction of fiscal norms helps to reduce the risks of the functioning of the Public Finance System, such norms should be in addition to balanced procedures for making budget decisions and the budget process in general and make the government live within its means.

Introduction of "fiscal rules" to restrict the provision of state support to certain sectors of the economy. As the experience of 2008-2009 shows, in Ukraine, the support of banking institutions turned out to be ineffective, since after receiving assistance, commercial banks did not perform active operations, that is, they did not resume their activities. In contrast to Ukraine, the governments of some EU countries provided support to those financial institutions that provided loans to the real sector of the economy. In 2009, in Ukraine, the amount of restructuring of banking institutions reached approximately UAH 20 billion (which amounted to $6.5 \%$ of the consolidated budget expenditures). To prevent the deployment of negative consequences in the future, it is necessary:

- at the state level, limit the provision of state aid to the financial sector;

- provide support to commercial banks only for lending to individual projects to high-tech industries with the potential for import substitution.

3. Provision of budget subsidies to support the creation of new or preservation of existing jobs in enterprises. Although the reduction in the number of employees leads to a decrease in the costs of the enterprise, at the same time it has additional pressure on consumption, thereby provoking a further economic decline. Thus, efforts to maintain employment benefit both the well-being of workers and economic recovery. Employee retention can also help businesses by avoiding the loss of valuable human capital.

Taking into account the world experience, the provision of state support should include the use of such budgetary instruments as: subsidies for the creation of new jobs (Slovakia); subsidies for the hiring of workers employed for more than six months (Great Britain); re-receipt by employers of a cash subsidy for each employee remained (Singapore); subsidizing enterprises with the aim of retaining workers and expanding jobs (Japan); granting grants for the creation and development of business (France, Russia); job creation (Czech Republic, Poland); attracting investments (Czech Republic, Poland); for environmental projects (Poland).

4. Optimization of the system of tax benefits and control over their use. Tax incentives should be aimed at the development of those segments of the economy that in the future will lead to an increase in revenues or a decrease in expenses due to the modernization of production, the release of new products or an improvement in its quality and competitiveness. In addition, it is also important to ensure:

- revision of the list of industries that are currently advisable to provide tax incentives. The advantage in granting benefits should be given to enterprises with high technologies, since in future they will achieve high indicators of economic activity, and, consequently, replenish the state budget through tax revenues;

- criteria for granting tax benefits. One of the consequences of the ineffectiveness of the provision of tax benefits are significant losses of budgetary revenues, and therefore it is necessary: when granting them, take into account the type of activity of enterprises, assess the impact of the benefits and the relevance of its application, assess budget losses and their impact on the socio-economic development of the country; clearly define the strategic goals of tax incentives, which consist in the future compensation of tax revenues that have not been received by the budget by modernizing production, releasing new products or improving its quality and competitiveness; the main condition for the provision of tax benefits is to determine the mandatory completion of an investment project;

- strengthening control over the use of tax incentives. In Ukraine, there are tax evasion schemes, therefore, it is necessary to search for effective methods of control over the use of tax incentives. Due to the existence of abuse of tax benefits and in order to purposefully use the funds freed from taxation to increase production volumes, re-equip the material and technical base, introduce the latest technologies, it is necessary to take into account the following: ensure appropriate state control and increase responsibility for the misuse of the released funds; introduce systematic reporting of the Cabinet of Ministers of Ukraine to the Verkhovna Rada of Ukraine regarding the amounts of tax benefits provided, as well as indicators of the economic and social efficiency of the tax benefits used during the relevant period. 


\section{Conclusions}

Increasing the efficiency of the use of public finances, which is of decisive importance for the economic development of Ukraine and increasing the well-being of citizens, can be achieved, in particular, by systematically improving the mechanisms of public administration of central and local executive authorities.

In our opinion, risk management is not a separate activity, but an integral part of management. The introduction of risk-based management aimed at achieving the goals set for the institution in general or in part of the direct industry responsibility of an industry leader, while avoiding or at least reducing the negative impact of miscalculations and surprises

The introduction of a risk-based public administration mechanism in the system of state internal financial control is an important guarantee of effective public administration reform, which will reduce the number of problematic issues related to the activities of public executive authorities and, accordingly, increase the country's competitiveness. So, for reducing the risks of public finances, consistent steps are needed to provide the budget with reliable sources of revenues, reform its expenditure side, as well as improve the budget process in order to create conditions for improving the quality and efficiency of budget decisions.

The paper analyzes the risk management of public finance in Ukraine, considers foreign in the period of crisis and suggests ways of improvement. If we consider the instruments for mitigating fiscal shocks during crisis periods, we will find many more different instruments used in world practice. COVID-19 pandemic has become a very clear indicator of what tools are ready to be used by different states, depending on their level of economic development and the degree of implementation of risk management in fiscal processes. High-income countries are characterized by the use of such budgetary instruments:

- application of fiscal rules. Most often, to minimize the negative impact of the risks of budget deficit is the use of fiscal rules. IMF experts recommend developing fiscal rules based on cyclically adjusted targets;

- implementation of budgetary expenditures of a social nature, in particular, budgetary subsidies during the crisis, included: subsidies to enterprises for the creation or preservation of new jobs, as well as for new / retraining; subsidies to enterprises for hiring workers employed for more than 6 months; subsidies to the enterprise for each employee remained;

- provision of incentives of an innovative and investment nature associated with additional risk, but the expected profit has to compensate for it.

The results of the study give grounds to assert that the improvement of the public finance risk management system should lies in the fact that these measures will provide priority assistance to business entities and the population, as well as provide an impetus for further economic growth. The result of effective budgetary incentives should be support for the sectors of the economy that are strategically important for the country.

Further research is required by theoretical and practical aspects of the application of these measures in Ukraine that will contribute to the activation of investment processes, innovative and technological modernization of production, form an innovative and investment model of economic development and will ensure the implementation of the priority tasks of stimulating structural transformations in Ukraine.

\section{References}

Androsova, O., \& Cherep, A. (2008). Banking operations. Kondor.

Bilousova, O., Harkavenko, V., Danylenko, A., Yershova, H., Zymovets, V., Koshyk, O., \& Chorna, O. (2013). Risks and threats to the financial security of the public finance sector and ways to overcome them. Academy of Financial Management.

Blishchuk, K. (2017). New approaches in public finance management. Effectiveness of Public Administration, 1(50), $208-214$.

Bondarenko, L. (2003). Basic instruments of management the credit risks of commercial bank are the promissory financing of investments. Ekonomika: problemy teorii ta praktyky: zbirnyk naukovykh prats, 170, 117-124.

Cabinet of Ministers of Ukraine. (2015, May 27). On approval of the strategy for increasing the efficiency of business entities in the state sector of the economy (No. 662-r).

Committee of Sponsoring Organizations of the Treadway Commission. (n.d). https://www.coso.org/Pages/default.aspx

Danylenko, A., \& Zymovets, V. (2015). Monitoring of factors creating risks of stability of public finances of Ukraine: scientific and analytical materials (pp. 2-13). Institute of Economics and Forecasting.

Drozd, I. K., Pysmenna, M., \& Pohribna, N. (2018). Implementation of the responsibility principle in the system of financial control of public procurement. Naukovyi visnyk Polissia, 2(13), 78-82. https://doi.org/10.25140/2410-9576-2018-2-2(14)-78-82

Everaert, G., Fouad, M., Martin, E., \& Velloso, R. (2009). Disclosing fiscal risks in the post-crisis world. International Monetary Fund. https://doi.org/10.5089/9781455241125.004

Grechanichenko, O. (2018). Risk-oriented management as a mechanism of public state financial management in Ukraine. Derzhavne upravlinnya: udoskonalennya ta rozvytok, 5. http://www.dy.nayka.com.ua/?op=1\&z=1238

Hasanov, S. (2017). Fiscal risks and fiscal targeting in public financial management system in the context of institutional uncertainty. Naukovi pratsi NDFI, 2, 5-24. https://doi.org/10.33763/npndfi2017.02.005

Internal Control Committee of the International Organization of Supreme Audit Institutions. (n.d.). https://ach.gov.ru/upload/ iblock/328/328e6dcf02c5e60c53e2442054c6aa56.pdf 
International Organization for Standardization. (2018). Risk management - principles and guidelines (ISO 31000). https://pqm-online.com/assets/files/pubs/translations/std/iso-31000-2018-(rus).pdf

International Standards of Internal Control in the Public Sector. (n.d). https://www.eurosai.org/handle404?exporturi=/export/sites/ eurosai/.content/documents/others/ISSAI/ISSAI-9100-RU.pdf

Kozoriz, L. (2020). International experience of minimizing fiscal risks in the context of macroeconomic shocks. Investments: Practice and Experience, 24, 72-81. https://doi.org/10.32702/2306-6814.2020.24.72

Lunina, I. (2012). Risks of state finances of Ukraine and ways of their minimization. Finance of Ukraine, 2, 4-15.

Lyuty, I., \& Kravchenko, M. (2014). Global economic crisis: threats and risks in the functioning system of public finances of Ukraine. Economy and State, 7, 24-27.

Miedviedkova, N. (2016). Directions for improvement of state financial control in Ukraine. Baltic Journal of Economic Studies, 2, 105-110. https://doi.org/10.30525/2256-0742/2016-2-2-105-110

Ministry of Finance of Ukraine. (2021). Information about fiscal risks and their impact on state budget indicators in 2021. https://mof.gov.ua

Moldovan, O. (2011). Risks of imbalance in the system of public finances in 2011 and directions of counteraction. https://niss.gov. ua/doslidzhennya/ekonomika/riziki-rozbalansuvannya-sistemi-derzhavnikh-finansiv-u-2011-roci-ta

Open Budget Survey. (2019). Open Budget Survey 2019: Ukraine. https://www.internationalbudget.org/open-budget-survey/country-results/2019/ukraine

Power, M. (2004). The risk management of everything: rethinking the politics of uncertainty. Demos.

Rozhko, O., \& Trygub, O. (2013). Threats to financial security in a changing world. Security Studies Review [Studia Securitatis], 2, 127-137.

Rozhko, O. (2013). Ensuring the stability of public finances in the context of the integration of the financial systems of Ukraine and the EU. Vestnik KJeU: jekonomika, filosofija, pedagogika, jurisprudencija, 3(29), 83-87.

Rozhko, O. (2016). The formation of new public finance management system within the framework of modern theory of public finance. Innovative Solutions in modern science, 9(9), 107-116.

Rozhko, O., Tkachenko, N., \& Kovalenko, Yu. (2020). Scientific and methodical approach to budget strategizing using the program-target method. Financial and Credit Activity: Problems of Theory and Practice, 2(33), 335-344. https://doi.org/10.18371/fcaptp.v2i33.206974

State Statistics Service of Ukraine. (n.d). http://www.ukrstat.gov.ua/

Varnaliy, Z., Onishchenko, S., \& Masliy, A. (2016). Threat prevention mechanisms of Ukraine's economic security. Economic Annals-XXI, 159(5-6), 20-24. https://doi.org/10.21003/ea.V159-04 